\title{
Synthesis
}

\section{Complex Land Systems: the Need for Long Time Perspectives to Assess their Future}

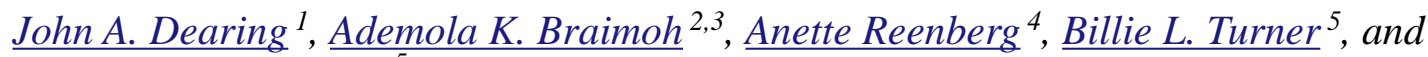 \\ Sander van der Leeuw ${ }^{5}$
}

\begin{abstract}
The growing awareness about the need to anticipate the future of land systems focuses on how well we understand the interactions between society and environmental processes within a complexity framework. A major barrier to understanding is insufficient attention given to long (multidecadal) temporal perspectives on complex system behavior that can provide insights through both analog and evolutionary approaches. Analogs are useful in generating typologies of generic system behavior, whereas evolutionary assessments provide insight into site-specific system properties. Four dimensions of these properties: (1) trends and trajectories, (2) frequencies, thresholds and alternate steady states, (3) slow and fast processes, and (4) legacies and contingencies, are discussed. Compilations and analyses of past information and data from instruments and observations, palaeoenvironmental archives, and human and environmental history are now the subject of major international effort. The embedding of empirical information over multidecadal timescales in attempts to define and model sustainable and adaptive management of land systems is now not only possible, but also necessary.
\end{abstract}

Key Words: adaptation; complex systems; Global Land Project; land systems; multidecadal timescales; resilience; socioecological systems; sustainability science

\section{INTRODUCTION}

\section{Land Systems}

Climate change continues to be a major research thrust within global environmental change and sustainability research, but with increasing emphasis on how society may adapt to future stresses. At the international level, this emphasis is visible within global environmental-change research reports and agendas, such as those of the Intergovernmental Panel for Climate Change (IPCC), the Millennium Ecosystem Assessment (MA), the International Geosphere-Biosphere Programme (IGBP), the International Human Dimensions Programme on Global Environmental Change (IHDP), and the newly minted Programme on Ecosystem Change and Society (PECS). Among these, the IGBP (2008) defines urgent research needs in terms of identifying thresholds or tipping points, regions where society is vulnerable to climate, that is, climate hotspots, and "climate information systems" for adaptation. Carpenter et al. (2009) summarize the priority needs for managing ecosystem services. They identify the need to improve the means by which socioenvironmental systems are anticipated and managed in the face of likely or projected changes in, for example, climate, biodiversity, resource use, demography, economics, and governance from global to local scales.

The Global Land Project, sponsored by IGBP and IHDP, focuses on "land systems" (GLP 2005): the kind, amount, distribution, and pattern of land uses and covers, among major socioenvironmental systems (Turner et al. 2007). Assessing land-system dynamics requires attention to processes operating at different spatial and temporal scales, to interactions between different drivers and, especially, to policy shifts that often lead to emergent properties and nonlinear outcomes. As it becomes more apparent that future societies may be exposed to multiple, simultaneous perturbations and stressors (e.g., Leichenko and O'Brien 2008, 
Rockström et al. 2009, Turner et al. 2007), and not just climate change, national emphases on the means to understand and manage land systems are becoming stronger and clearer, for example, in the UK (Living with Environmental Change) and USA (United States Global Change Research Program).

At the same time, we are beginning to see a change in our understanding of the nature of interactions between the social-economic-cultural and the biophysical environment. Well into the $20^{\text {th }}$ century, the dominant public view in the Western World envisioned humans as adapting to or improving environmental dynamics through changes made in the environmental subsystem at regional scales (Marsh 1864, Thomas Jr. 1956). Subsequently, that view has shifted to encompass the detrimental effects of human stresses at the scale of the earth system (Turner et al. 1990, Steffen et al. 2004). This shift is part of a wider reconceptualization of how to view, investigate, and deal with socioenvironmental dynamics (Newell et al. 2005). New avenues of research now define societal and ecosystem interactions, vulnerability, and resilience (e.g., Elmqvist et al. 2003, Turner et al. 2003, Eakin and Luers 2006, Diffenbaugh et al. 2007) as part of the process by which we assess what knowledge is required to anticipate future impacts.

This process acknowledges that the condition and consequences of land systems involve multiple tradeoffs of climate and other stressors within and among social and environmental subsystems. Some of these stressors are environmental, such as the acidification of the oceans or the impact on ecosystems of phosphorus in runoff, where there is already increasing evidence that the environmental subsystem is approaching potential thresholds (Pielke 2006, Lenton et al. 2008, Rockström et al. 2009). Stressors inherent in the dynamics of the human subsystem involve demographic, economic, governance, and environmental-perception factors. In many situations, these are brought about by societal transformations that are altering the context for adaptation to climate change (Liechenko and O'Brien 2008). The subsystems involved tend to respond more quickly and strongly to extreme events than to changes in their mean operating conditions. This implies that when these subsystems are coupled, the responses to multiple stresses may be amplified by positive feedback, resulting in a high probability of crossing thresholds (Doherty et al. 2009, Rockström et al. 2009). Therefore, understanding and anticipating the outcomes of these coupled dynamics is made difficult by the multiplicity of processes operating over various spatial and temporal scales with the associated unpredictable properties (e.g., Liu et al. 2007). A focus on any particular subsystem or preoccupation with simplistic causation will fail to deal with the real challenge of reducing uncertainty in regional land systems.

\section{The Need for Long Timescales}

It is well understood in climate-change research that the temporal scale of assessment affects the understanding of the dynamics and outcomes observed; subdecadal observations may run contra to decadal or centennial ones. Here, we argue that assessments of multiple stresses acting on complex and coupled land systems are similarly affected, demanding a new and explicit focus on multidecadal timescales of past information that are longer than those normally represented by observational and instrumental data (Dearing et al. 2006a). Therefore, a major research priority for sustainability science is not only place-based and comparative, but longterm (Carpenter et al. 2009).

In the absence of such a focus, we will be unable to view some of the slow, decadal-centennial or even millennial trends in environmental and cultural dynamics that define stability. Nor will we be able to identify the existence of second-order changes, such as changes in the perception of challenges as a society evolves, or changes in the land dynamics that are because of continued appropriation of the environment by that society. Likewise, assessing the types of threshold change inherent within a system and the likelihood of transgressing thresholds in the future is daunting without the benefit of hindsight (cf. Lenton et al. 2008). Also, the predictive value of models is substantially increased where the models are shown to simulate known changes over the same decadal time span as desired for the future.

Without a long-term perspective, we impose an a priori limit on the total number of states of the socioenvironmental system that we are able to study and understand, and bias our knowledge toward the heavily perturbed system states observed in the recent past. This is comparable to examining a seriously ill patient without knowing what a healthy one looks like. In short, without a long-term focus, our understanding of the evolution of socioenvironmental 
systems will likely inhibit robust assessments of the challenges facing us. Some notable exceptions notwithstanding (Turner et. al. 1995, Foster and Aber 2004, Turner et. al. 2004), current assessments of existing land systems or their future states are often flawed by the sparse attention to timescale.

At the outset, two potential barriers face attempts to construct long-term perspectives for land systems. First, a framework for studying land systems would ideally encompass the whole range of relevant temporal (and spatial) scales from the very long, multimillennial to the very short (annual, seasonal or even shorter), even though in practice the relevance of any timescale cannot normally be known a priori. However, the practitioners of the study of these different timeframes are weakly linked within the research community (Dearing $2007 a$ ), even though their joint efforts are crucial for determining the full range of temporal variability within a system.

Second, there is a paradox implicit in the study of long timescales that is exemplified by the Anthropocene (Crutzen 2002, Steffen et al. 2004). A long timescale of observations was needed to place the contemporary world in its historical context and to identify the growing impact of human activities on the Earth's system. However, the rapidity of contemporary change is such that the natural and social-science research communities alike have not fully come to terms with the noanalog implications of the Anthropocene, especially in terms of whether the pace of recent change (Steffen et al. 2004) renders useful comparisons to the past difficult-or invalid. This issue is further complicated by the growing recognition that complex systems demand analysis of dynamic behavior, which shifts the emphasis away from equilibrium to nonequilibrium approaches. It is, perhaps, excessive to conclude that stationarity is completely dead, as some have asserted for water resources (Milly et. al. 2008), but the point is well taken: understanding coupled system dynamics, land or other, requires attention to changing boundary conditions and the possibilities that multiequilibria may exist (e.g., Berkes et al 2003). Therefore, the epistemological basis for learning from the past, especially with regard to the analog approach, demands further discussion.

\section{Uses of the Past to Inform Land Systems: Analog and Evolutionary Approaches}

Learning from the past to inform current and future assessments of land systems has conventionally focused on analogs (Meyer et al. 1998, Costanza et al. 2007). In most cases, past states of land and resource-use systems are more or less disconnected from the present insofar as few processes function in ways that are continuous across the whole timescale or that are common to both the past and present states. In this sense, the analog serves largely as a heuristic. These heuristics, especially those directed toward the public at large, tend to use an unsustainable trajectory or outcome of a past system, such as resource stress and climate change, as providing broad dimensions or understanding of a current complex system (e.g., Glantz 1994, Landes 1998). Examples include the resource stress on Easter Island (e.g., Diamond 2005), the collapse of Classic Period Maya civilization because of land stress, warfare, and climate change (Gill 2001, Haug et al. 2003), and the end of the Roman Empire because of its overextension and excessive administrative overhead coupled with financial mismanagement (e.g., Tainter 1988).

Heuristic analogs offer insights into differences and similarities among cases, and sensitize the expert and public communities about possible surprises and response options (Meyer et al. 1998). However, such analogs are imperfect matches with the present, especially with regard to technological and sociopolitical conditions of the human subsystem, and often inappropriate (Meyer et al. 1998, Wescoat 1991). The complexity of land systems, particularly as it affects system outcomes, is a major reason why sustainability science orients itself toward placeand time-based assessments (Kates et al. 2001). In addition, past case studies tend to be overrepresented by disasters and unusual situations, biasing the lessons that may be gleaned from them.

Thus, analogs prove problematic for systematic assessments of current and future land systems, especially as boundary conditions change. However, by studying a substantive number of instances of land dynamics over sufficiently long time periods, even if disconnected from the present, we may be able to generate models that are initially conceptual, and later perhaps quantitative, of the interaction of a number of the more general processes to which such systems are subject (e.g., Zhang et al. 2007). For example, the kinds and 
magnitudes in the drawdown of certain ecosystem services that serve as tipping points in the environmental subsystem may be revealed. Following Tainter (1988), it may be possible to derive a typology of land-system behavior related to complexity theory, such as the apparent fragility of strongly interconnected systems. Given the uncertainties and assumptions embedded in ancient human subsystems, the phenomena that we are interested in studying, such as structures of resource entitlement, may be better served by case studies in which written records exist. Nevertheless, comparisons of a sufficient number of standardized land-system histories may enhance systematic assessments of postulated generalized complex system behaviors (Integrated History and Future of People on Earth 2009). This more systematic use of analogs fuses into the second means of drawing on the past to inform the now and future.

In contrast to analogs, an "evolutionary" view of the past focuses on long timescales where the present remains continuously and strongly connected to the past, described elsewhere as extending the present to define a "long now" (Brand 1999, Carpenter 2002). These connections address processes that may operate over long timescales, are repeated regularly, or involve time lags, contingencies, emergent effects, or past legacies that are integral to the functioning of the contemporary and future system. Studies that connect the present and past by integrating observational, documentary, and reconstructed data provide a perspective that may be critical to understanding all the elements of contemporary system dynamics (Fig. 1). Importantly, long time series of data and information may be the only means by which to confirm the existence of theoretical or conceptual complex system behavior, e.g., alternative steady states, the adaptive cycle, contingent and emergent properties, and feedback mechanisms, in a real-world system.

In the context of global environmental change, the more that societies face no-analog situations, the more this long and continuous perspective becomes critical. In this nonanalog, evolutionary context, we can ask fundamental questions that are relevant to any contemporary land system. Where in a system do positive feedback mechanisms exist? How have they evolved? How long is their path? What are the key contingent states? How have fast and slow processes interacted to create the feedback mechanisms? Which complex dynamics operate? With this information, how do we anticipate and manage future states? Long timescales are crucial to addressing these types of questions in at least four different, but not mutually exclusive, dimensions.

\section{FOUR DIMENSIONS OF LONG TIMESCALES FOR LAND SYSTEM ASSESSMENT}

\section{Trends and Trajectories}

Signatures indicating the form and direction of change are important to understanding the dynamics of contemporary land systems. They signify the magnitude of change from past periods to the present, possibly indicating how far from an equilibrium state the present system or subcomponents are. Without the long perspective, it is difficult to distinguish between linear, or first order, and accelerating / decelerating, or second order, change. Steffen et al.'s (2004) compilation of global social and environmental processes allows definition of the period since the 1950s as "The Great Acceleration," vividly illustrating the accelerating pressures, losses, and exploitation of resources (Fig. 2). In the ancient past, we have also observed the accelerating trends of escalating resource and land demands in many case studies, for example, the Easter Islands or Maya heartlands. Such evidence focuses attention on the potential dangers of convergent stressors on modern society and the environment set within "perfect storm" scenarios (Beddington 2009). We may presume that similarly accelerating trends are common for many regions and local scales, such as the desiccation of the Aral Sea, but few systematic subglobal assessments of the magnitudes and rates of socioenvironmental change exist over decadal timescales.

There are attempts to define the environmental health of regions through analysis of recent environmental trajectories; for example, the work on socioenvironmental syndromes (e.g. Lüdeke et. al. 2004), or the European typologies of regional environments (European Spatial Planning Observation Network 2006), and the comparison of regions at risk (Kasperson et al. 1995). However, with exceptions such as Meybeck's (2003) typology of river water-quality regimes, these are essentially based on relatively short records obtained from census, instrument, and satellite-image data. An extended, quantitative temporal dimension drawn from environmental history and palaeodata 
Fig. 1. Slow and fast processes.

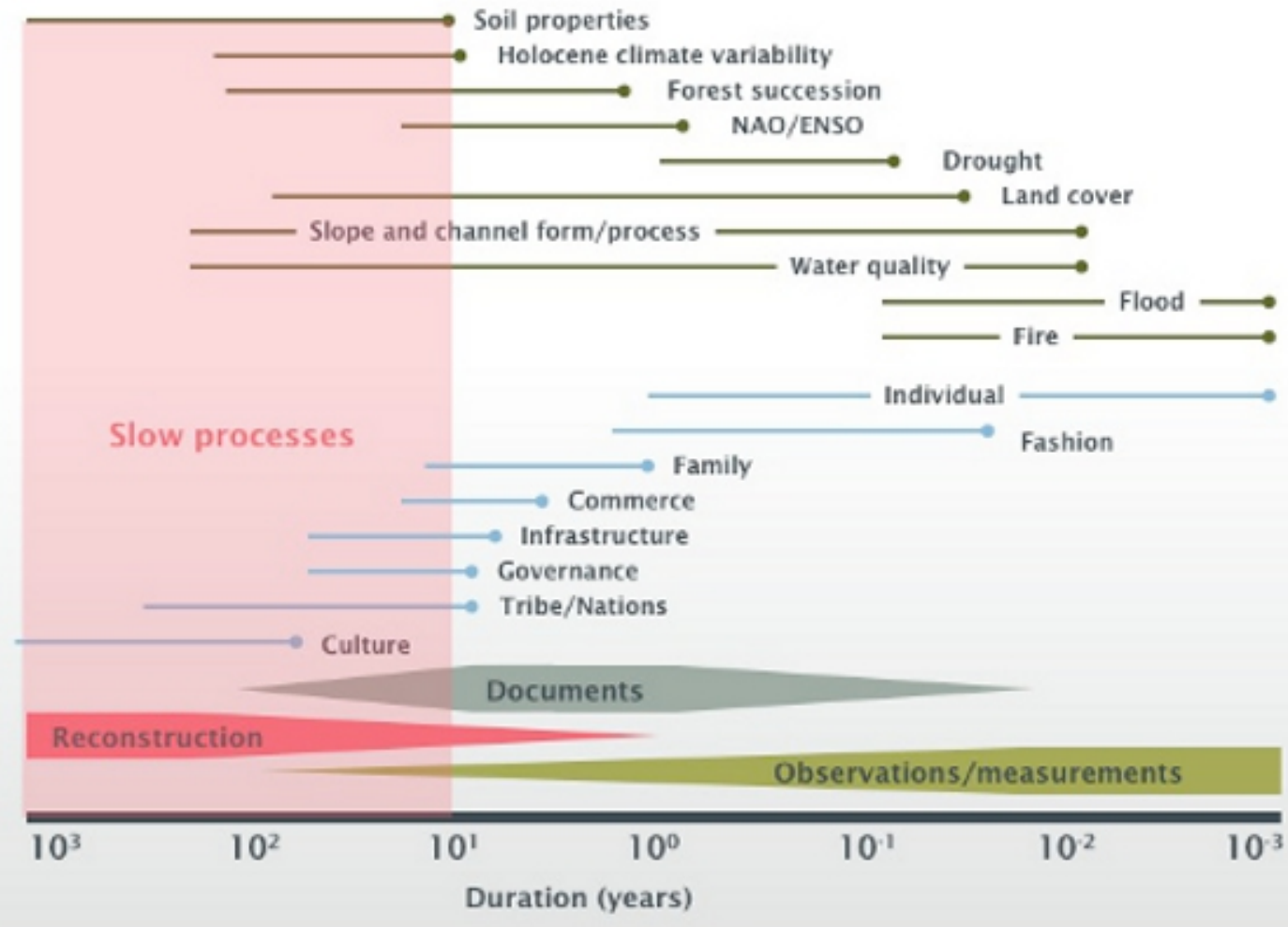

Note: Timescales for a range of biophysical and socioeconomic phenomena range from "fast" subannual events (e.g., floods, fire) to "slow" multidecadal and centennial changes (e.g., culture). Understanding contemporary socioecological systems may require information from a similar range of timescales, but sources of information become more limited for longer timescales. The sources of information available for each segment of timescale with respect to the present are depicted by the lower horizontal bars. Observations and measurements (e.g., instruments, remote sensing, censuses, economic statistics), and documents (e.g., diaries, gazetteers, land use descriptions) may only be available for relatively short timescales. Changes over longer timescales of change that are essential for assessing the role of "slow" processes (the thick vertical bar) may need to be reconstructed. Reconstruction covers all the palaeoenvironmental fields, including archaeology, palaeoecology, palaeoclimatology, and palaeohydrology, that interpret artifacts and natural sediment archives (e.g., lake sediments, stalagmites, peat) in terms of past environment and society. After Oldfield (1983) and Brand (1999).

provides a more robust basis for examining the trajectories (e.g., Dodson and Mooney 2002) of relatively slow processes, such as changes in water quality, rates of geomorphic instability, or the evolving nature of socioenvironment interactions (e.g., Geist and Lambin 2002, Parton et al. 2007, Stafford Smith et al. 2007). The ecological processes and human activities of land systems can be strongly interdependent across spatial and temporal scales (Kasperson et al. 1995). Thus, integrating a range of different types of long-term records can provide comprehensive environmental profiles of that interdependency (e.g., Olson et al. 2008).

Trends may also signify emergence: evidence for bottom-up processes interacting at a local scale producing higher-level structures that are both qualitatively different from their lower-level constituents and not obtainable through simple 
Fig. 2. Trends and trajectories.

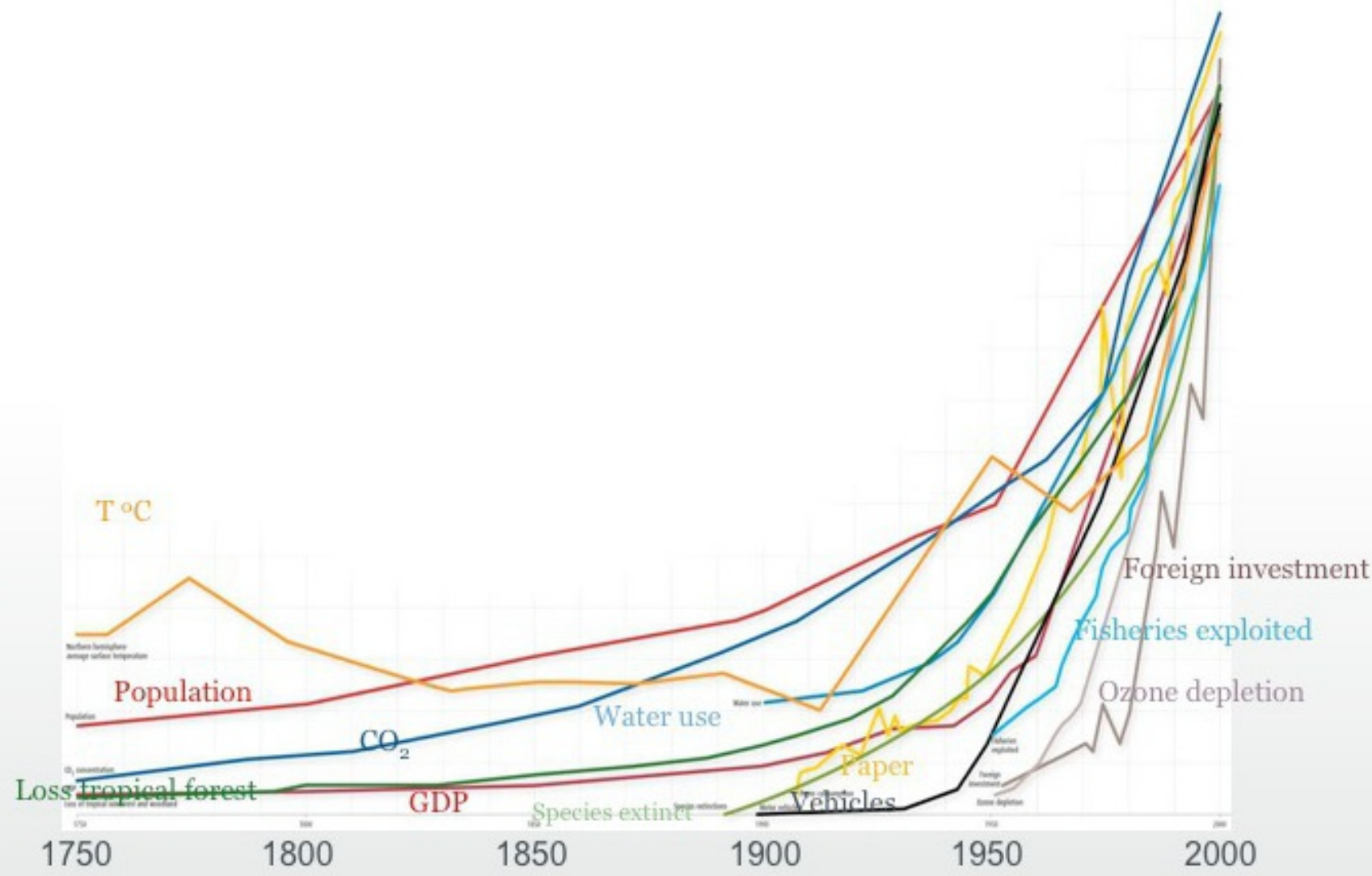

Note: Changes in global states and processes since AD 1750, including ecological services, climate variables and economic data, show systematic acceleration in rates from the mid- $20^{\text {th }}$ century: the Great Acceleration. After Steffen et al. (2004), redrafted at http://rs.resalliance.org/2008/12/04/visualizing-thegreat-acceleration-part-ii/.

aggregation of microlevel components (Auyang 1998). Many, if not most, high-level forms and structures in land systems are emergent, (e.g., Lansing and Kremer 1993, Ostrom 2009), including land-tenure patterns, governance structures, trading agreements, agricultural ecosystems, irrigation systems, and river patterns. The importance of emergent forms is less with their identification than with the elucidation of how they have evolved. For instance, collective action is shown to influence land use in ways different from the effect of individual households (e.g., Bousquet et al. 1998, Rouchier et al. 2001, Nagendra 2007), and the totality of individual land-use decisions may trigger regional changes in precipitation (e.g., Pielke et al. 1999, Malhi et al. 2007). Such examples are extensively documented for recent decades, but two studies demonstrate the increasing realization that longer multidecadal and even centennial perspectives may be important.

The first study integrates environmental history, geomorphological investigations, and lakesediment records from the English Lake District stretching back several centuries (Chiverrell 2006). It makes a compelling case for landscape instability 
being the result of major changes in land use rather than climate, particularly overgrazing and rapid reductions in woodland/shrub cover. This implies that the recent ending of the European Union Sheep Annual Payment Scheme, where payments are scaled to stock levels, should have beneficial effects in terms of reducing overgrazing and encouraging land stewardship. However, managers who address the objectives of the Lake District Environmental Sensitive Area plan also need to be aware of the likely sensitivity of soil degradation to future clearance or burning of secondary woodland/scrub.

The second study contrasts in scale and context, but the approach taken is similar. The Murray-Darling basin is possibly Australia's most critical resource management issue, with $95 \%$ of its river length degraded (Gell 2007). The Murray lakes and lagoons are under pressure from different stressors, with the Coorong coastal wetlands, an internationally significant site (Ramsar Wetland C onvention), a particular concern. An integration of decadal-millennial reconstructions of water quality (diatoms) and land cover (pollen) at many sites with land-use histories and hydrological modeling allows reconstruction of interactions and feedback through space and time (Gell et al. 2007). The diatom studies show that many wetlands have been degraded for over $100 \mathrm{yrs}$ as a result of land clearance that started more than 200 yrs ago. This means that restoration of the Coorong system is a greater task than was expected in a government decision to use 1985 as a baseline target. Revegetation initiatives to combat soil erosion and soil salinity are planned, but these may reduce river flows at a time when climate change is projected to drive down runoff by as much as $25 \%$ already by 2030 (Gell et al. 2007). A 200-yr trajectory has now left managers with very few options that can satisfy international agreements for conservation as well as the needs of agriculture and water-resource users.

These examples underline the need for regional integration of multidecadal data for socioenvironmental processes. This need is particularly important to the development of policies and strategies in regions where successful management of key environmental processes, ecological services, and their interaction is critical: for example, within "wildlands," biodiversity hotspots, areas projected to experience climate change extremes, or socioenvironment systems projected to be particularly vulnerable to combinations of stressors (Dearing et. al. 2006 $b$, Past Global Changes 2009). Such regional integration is essential if we are to gauge whether trends leading to the present are divergent or convergent: the former suggesting that we may be able to deal with stress effects of drivers individually; the latter implying that drivers of change may in the future interact to compound their effect. This information helps determine the likely stress levels in the future and, logically, the array of choices that society is able to make.

\section{Frequencies, Thresholds, and Alternate Steady States}

Trends provide historical perspective for contemporary land systems, but concern about the future of land systems often focuses on the likelihood of abrupt change, the changing magnitude and frequency of predictable events and the possibility that unpredictable change across a threshold may push the system to a new state. Scheffer et al. (2001) review such changes in ecological systems, emphasizing the idea of a stability landscape that changes its shape through time, while Lenton et al. (2008) have identified a number of potential tipping points in the earth system based on analysis of changes reconstructed from palaeoenvironmental records. They caution against the use of past changes in making projections for the future because the boundary conditions under which they occurred were different from today and anthropogenic forcing is generally more rapid and different in pattern. Nevertheless, the ranking of potential thresholds has made a large contribution to the debate on the possible consequences of global warming.

For socioenvironmental systems, there are already 270 recorded threshold transgressions of key ecological states and services at regional-local scales (http://www.resalliance.org/183.php), but information is still lacking for key land-system types. New datasets for key land systems would add considerable value to our understanding of the nature and timescales of "typical" threshold transgressions and help gauge the possibilities for recovery from ongoing or projected disturbances. We have many examples of threshold transgressions in ancient land systems (e.g., Redman 2001, Lawrence et al. 2007), and there is scope for more systematic, spatiotemporal analysis of the processes occurring in these instances to provide generic insights about thresholds (e.g., Whitmore et al. 1990). This might help mitigate the paucity of 
information about threshold transgressions in recent history that directly affects contemporary land systems.

For example, it has been shown that the recent vulnerability of the Sahel to climate is impossible to gauge without an extended temporal perspective. Historically, systemic resilience was created through the diversification of livelihoods, and it seems that systemic thresholds were crossed only recently (Reenberg 2009). The nomadic cultures that developed around pastoralism over the last 5000 yrs became well adapted to the unpredictable resource base (Brooks et al. 2005). However, in the 1950s and 1960s, the Sahel experienced unusually high rainfall that coincided with the independence of the nation states in the region. This concatenation of societal and environmental events created a large incentive to increase the number of settlements that, in turn, had profound implications for the vulnerability of the agricultural system. Cultivation expanded into marginal lands and influenced future vulnerability, essentially driving the land system across an irreversible threshold. In contrast to the times before 1950, the intra-annual and interannual variability of rainfall in the $21^{\text {st }}$ century has lessened the ability of the land system to sustain the significantly increased local population with food in any given year (Reenberg et al. 1998, Nielsen and Reenberg 2009a, $b$ ).

Whether or not rapid change is actually a threshold transgression or part of the natural variability of a system is often only possible to discern with hindsight. Land systems continuously vary in terms of process and state conditions over a range of timescales described in different terms in different fields, for example, as "magnitude and frequency" in hydrogeomorphology (Wolman and Miller 1960) and "risk spectrum" in hazard assessments (Cutter 2001). Sometimes an analysis of long-term variability, that is, changes in the frequency of events, for example, provides important insights into how human activities have modified the probability of extreme events and transgression of thresholds. In the southwest United States, for example, comparison of 400-yr fire-frequency records (fire scars in trees) with land-use histories (Fig. 3) shows that fire suppression measures have been instrumental in reducing the frequency of small-medium sized fires since 1900 (Swetnam et al. 1999). Contemporary statistics show that many sites are now at risk from catastrophic standreplacing fires as dense scrub thickets fuel non- natural fire patterns. Such long-term studies of variability tend to confirm the view that contemporary human activities tend to push the risk spectrum toward catastrophic events occurring with increasing probability.

A corollary of abrupt change is that observations of contemporary environmental conditions restrict the number of system states that we can study; a shortterm perspective may be unrepresentative of alternative states (e.g., Dearing 2008) that are actually desirable for the goals of management. Where society is bound to choose a reference state as a management target, a short-term perspective is constraining. This is exemplified by actions to implement the 2002 European Union Water Frame work Directive. The Directive requires all Member States to determine reference conditions for aquatic ecosystems that can act as a baseline against which to measure effects of past and present activities. It requires an evaluation of those conditions expected under minimal human impact and has, as a principal goal, to achieve "good ecological quality" by 2015. As Bradshaw et al. (2006) and others have shown, early attempts at gauging conditions associated with minimal human impact were flawed. In Denmark, early suggestions that 1800 levels of phosphorus in lakes could be considered the realistic target for restoration were put into doubt by reconstructions of total phosphorus in lake cores. The core data showed that highest values occurred in the 1950s and, importantly, phosphorus levels have been rising since 300 with an abrupt rise after 1100 .

Anticipating when a threshold change will happen is obviously a key concern for policy makers. Some progress in this domain has come from time-series analyses of model output for socioenvironmental systems that show the variance or volatility of the system rising $\sim 10$ yrs before the shift from one steady state to the other (Biggs et al. 2009). Whether the same approach may be applied to empirical data that describe socioenvironmental systems is unclear, although one intriguing analysis of historical macroeconomic data reports a harmful effect of volatility on economic growth (Hnatkovska and Loayza 2004).

\section{Slow and Fast Processes}

In a complex system, the interaction of trends and frequencies is essentially the interaction of "slower" and "faster" processes. Of particular importance in 
Fig. 3. Frequencies, thresholds, and alternate steady states.

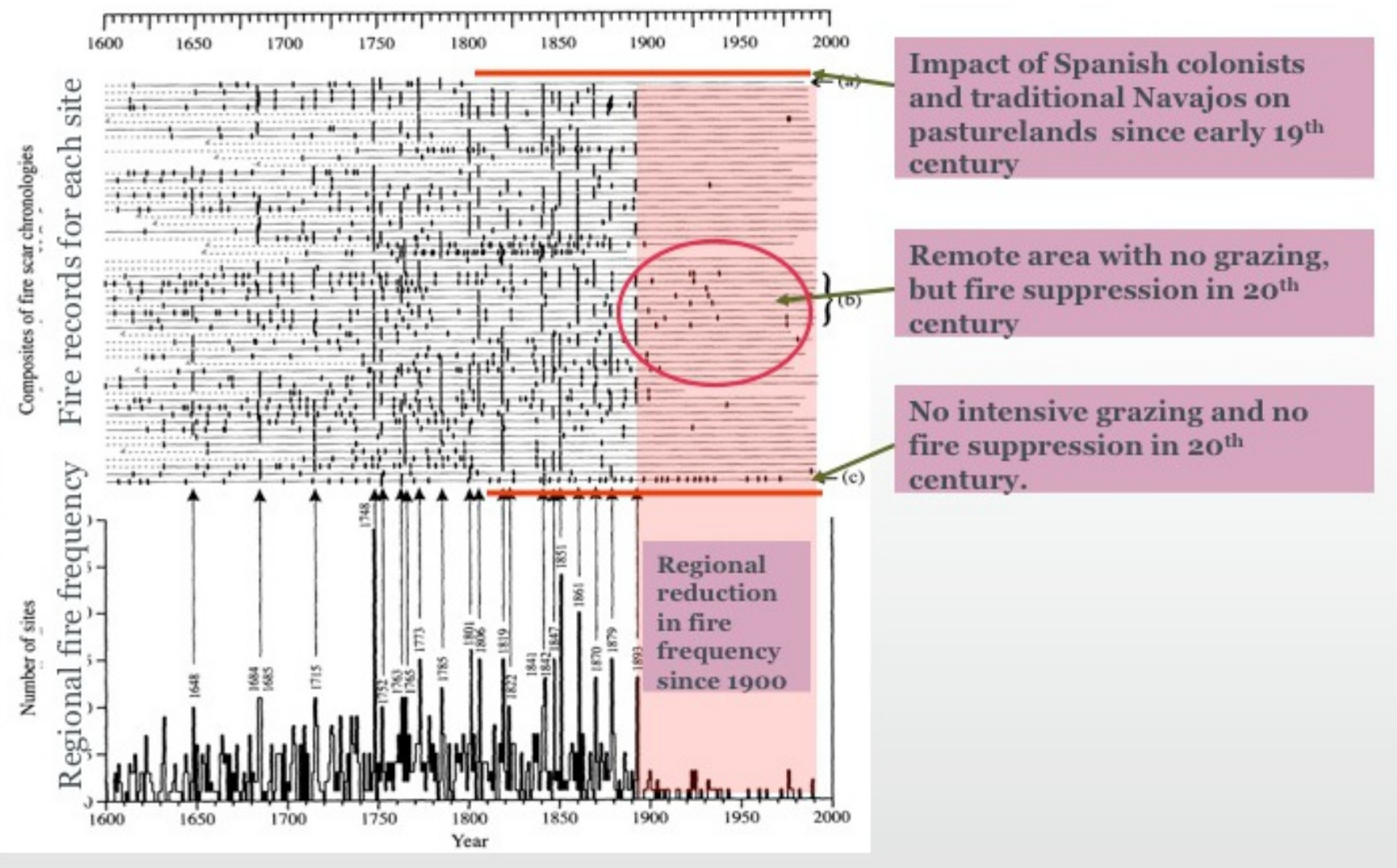

Note: Records of fire scars (moderate surface fires) from many sites in the southwest United States show the effects of different combinations of historical grazing regimes and modern fire suppression. Most show a reduction in fire scars from the end of the $19^{\text {th }}$ century, largely as a result of intensive grazing. Exceptions strengthen this inference, for example: a) Spanish colonists on traditional Navajos pasturelands since the early $19^{\text {th }}$ century; b) remote area with no grazing, but fire suppression in the $20^{\text {th }}$ century; c) no intensive grazing nor fire suppression in the $20^{\text {th }}$ century. Contemporary statistics show that many sites are now at risk from catastrophic "stand-replacing" fires as dense scrub thickets fuel non-natural fire patterns. After Swetnam et al. (1999).

the evolutionary view is the ability to identify the timescales over which each of the major processes in question operates, sometimes stretching over several orders of magnitude (Fig. 1). In effect, identifying the timescales at which the different processes in a land system operate is often a very effective way to separate relevant and irrelevant information about land system vulnerability and resilience (Gunderson and Holling 2002), to decide which of these processes is essential or subordinate to the dynamics of the system (van der Leeuw and Aschan-Leygonie 2005) and, thus, to identify the loci of effective innovation and management. In the Yunnan Mountains in southwest China, for example, phase-space analysis of land-use and environmental-process records suggest that soil erosion and land cover should be considered as slower processes operating over decades-centuries relative to the faster monsoon intensity and flooding (Dearing 2008).

This relationship between process speed, and the resilience and vulnerability of a land system, is evident in the case of the Haut Comtat in France, a 
region that was hit by two successive agricultural "crises" in the 1870s and the 1970s. The first crisis combined a rapid outbreak of the vine aphid phylloxera that affected wine production and the coincidental opening of the railway to Paris. These two events triggered an immediate search for a new agricultural economy. Newly installed irrigation, coupled with small-scale experimentation with horticulture, enabled a rapid response that maintained the land system. In contrast, in the 1970s, the crisis occurred as a result of the agricultural economy becoming slowly undermined by competition from Italy and Spain as a result of greater European union. The regional land system was not able to deal effectively with these changes and the human subsystem suffered a prolonged economic crisis throughout the 1980s and 1990s (van der Leeuw and Aschan-Leygonie, 2005). Systematic comparisons of such cases can help to reveal the character of the slow and fast events and coupled system conditions in which they operate.

Identifying the relatively slow processes may shed light on the processes that determine system resilience (Gunderson and Holling 2002). Resilience is related to stability, often portrayed as a target property for management, but not always. For example, in development terms, Stafford Smith et al. (2009) note that for some dryland regions, the main issue is not to increase resilience. They portray the development of resilient socioenvironmental systems that are undesirable in terms of vulnerability to drought and low carrying capacity. For these land systems, they argue that the key issue is how to increase transformability to enable change from the current type of system to a more preferable system. This may entail modifying livelihoods, developing new goods and services, and operating at different scales (Reenberg 2009). Again, systematic comparison of land-system histories may prove useful in identifying the nature of resilience in undesirable land systems as well as the levers that may transform them.

\section{Legacies and Contingencies}

Long timescales are necessary to observe the changing nature of interactions among system components. As the land system of interest becomes more affected by human activities, the interactions may extend further across time and space. In systems terms, the hierarchy of organization may increase with far-reaching cross-scale effects
(Westley et al. 2002). In the temporal domain, this means that contemporary system behavior may be subject to legacies and contingencies (Foster et al. 2003): that there is "memory" within the contemporary system. One approach to examining these phenomena is to compile parallel and independent time-series of data and information so that the evolution of interactions may be analyzed through time.

In the New Forest National Park (UK), recent observations suggest that the beech woodland is declining (Fig. 4). Various causes of the decline have been put forward, including recent grazing pressure and climate change, pointing to possible policy solutions for the land system. However, reconstruction of past forest dynamics and land-use history over the last 800 yrs shows that the development of beech woodland as it appears today has been dependent, or contingent, on a long history of past land practices stretching back several centuries (Grant and Edwards 2007). From a management perspective, the importance of understanding the extent to which contemporary system functions are contingent on past events is often essential to making accurate decisions about the land system.

An extension of this approach can help determine path dependency, the term given to describe a human-environment system that follows a selfreinforcing trajectory or path through continuous feedback mechanisms. Stafford Smith et al. (2007) illustrate this in their review of historical desertification events in Australia that elegantly combines analog and evolutionary approaches. They compile information for individual drought episodes in different locations since 1898 to help understand the reasons why land degradation repeats and intensifies, revealing a number of selfreinforcing steps in each case. Increasing commodity prices before a drought encouraged heavier stocking that, in turn, increased grazing pressure and reduced pasture quality. Each such episode accelerated arid land degradation. Overexpectations of stocking levels were based on moderate land conditions emerging between droughts. These conditions existed longer than the lifetimes of pastoralists, inhibiting learning and adaptation measures. Over time, the socioenvironment system became increasingly highly connected, maladaptive and "locked-in," limiting its freedom of choice, so that ultimately it was driven over existing environmental thresholds. 
Fig. 4. Legacies and contingency.

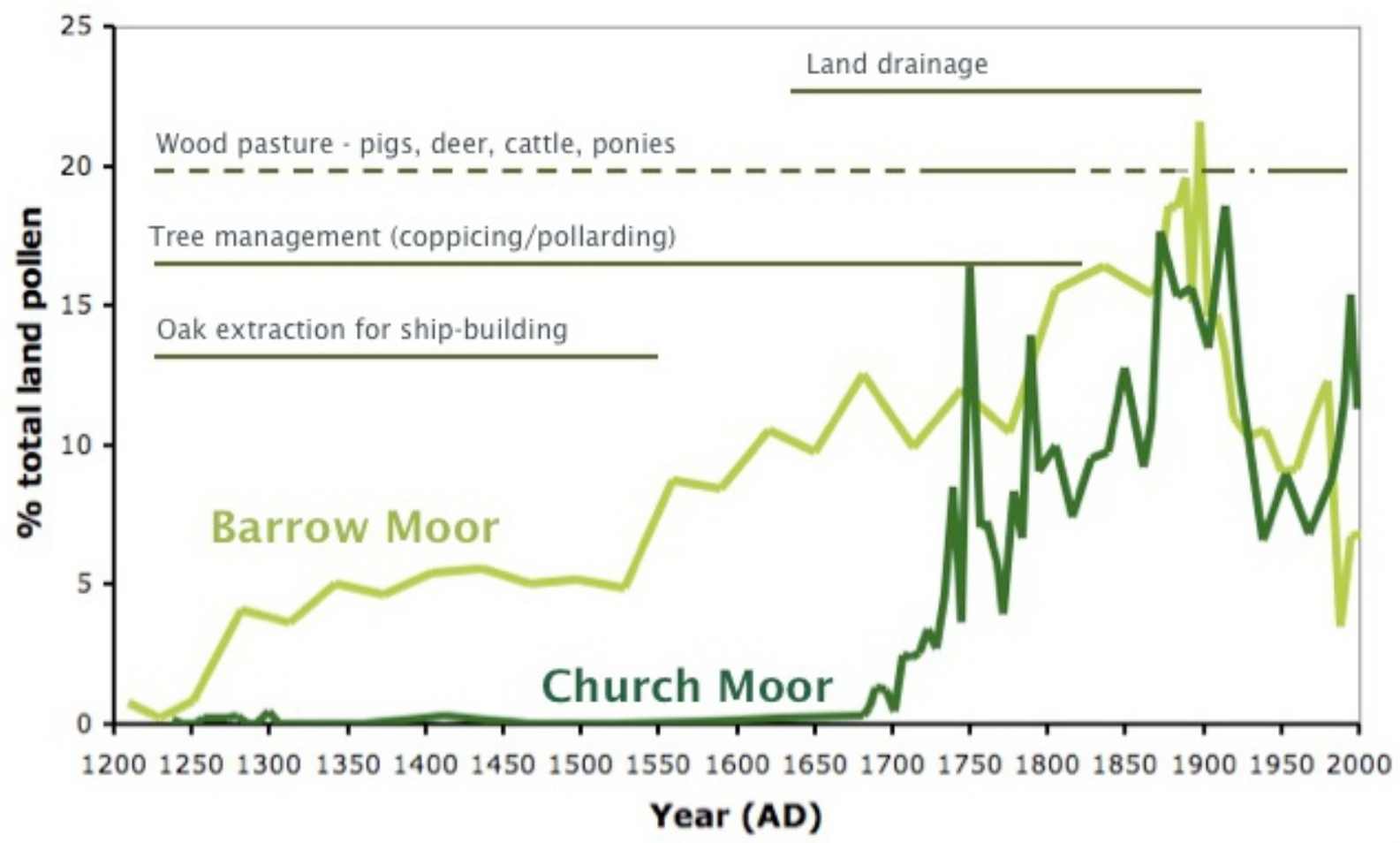

Note: The ecological structure of the Ancient and Ornamental Woodlands in the New Forest National Park, UK, is in part the legacy of long-term effects of land use since AD 1200. The two curves represent the growth and decline of beech trees (Fagus sylvatica), plotted as percentages of beech pollen in total pollen sum observed in two peat basins (Church Moor and Barrow Moor) within the forest. Although the two curves show similar trends, the different timings for the rise of beech suggest that beech is a relatively recent species contingent on local conditions that vary over short distances. The horizontal lines show the duration of several important land-use practices, including using the forest for pasturing animals, coppicing and pollarding, timber extraction for local ship-building, and land drainage. The rise of beech in the $18^{\text {th }}$ and $19^{\text {th }}$ century is most likely a legacy of the decline in other tree species such as the oak used in ship-building. Declining trends during the $20^{\text {th }}$ century are a result of the decline in traditional land-use practices coupled with greater vulnerability to wind-throw as the trees become taller and larger. Adapted from Grant and Edwards (2007).

\section{TOWARD NEW LAND SYSTEM MODELS}

At the global scale, outputs from climate models for a range of scenarios continue to dominate our view of the future of the earth system and to drive the political agenda for mitigation (IPCC 2007). At regional scales, impact assessment models (IAMs) are the main tools for agencies to engage with the questions of impacts, vulnerability, adaptation, and sustainable management (Grimm et al. 2008). But
IAMS, such as those based on Driver-ProcessState-Impact-Response frameworks (e.g., Spangenberg et. al. 2009) are not beyond criticism.

Tallis and Kareiva (2006) argue that they frequently lack key feedbacks, are unable to predict thresholds, and make poor connections between ecosystem services and human well-being. As valuable as they are as frameworks for the classification of information for policy makers, IAMs should not be 
used as a causal scheme (Spangenberg et. al. 2009). Projections of some environmental phenomena, such as species distributions through the use of bioclimate envelopes, may use the wrong spatial scale to define species niches (Willis and Bhagwat 2009) and by their nature ignore the fundamental complexity of the systems and the distinct possibility that boundary conditions may be rapidly changing. Oldfield (2005) highlights the lack of rigorous testing of model outputs against past data. Even where long temporal perspectives are valued, such as the historical profiling approach used by the resilience community (Walker et al. 2002), there is a tendency to use historical information to contextualize the system rather than to use it in ways that explicitly embrace an evolutionary approach.

As the sustainability agenda (Kates et al. 2001) grows stronger, thus there is a growing call for modeling tools that can simulate future system states while capturing essential nonlinearities and complex behavior (e.g., Nicholson et al. 2009). In these analyses, success is measured by an ability to understand the fundamental but realistic dynamical behavior of the system, if needs be at the expense of accuracy. This challenge is taken on through the development of relatively new types of system analysis and simulation modeling.

In theory, modeling the complexity of land systems over decadal timescales should be enabled by the use of bottom-up approaches that evolve change and emergent phenomena through continuous interaction and feedback (Dearing et al. 2006 b, Dearing 2007b). These models include reduced complexity cellular automata-type approaches (Coulthard and Macklin 2001) and agent-based models (Bonabeau 2002) based on the operation of rules. The rules for many biophysical processes can be modeled using established, and sometimes universal, low-level mathematical algorithms, for example, water flow. In contrast, the high-level rules for social processes are usually statistical in nature, necessarily based on local surveys of likely human behavior, for example, land preferences, and underlined by the assumption of rationale behavior. These models have been used successfully to simulate land-use decision making (Parker et al. 2003), to test hypotheses about past cultural shifts (e.g., Dean et al. 2000) and to experiment with the effects of different weightings of climate and land use on landscape processes (Coulthard and Macklin 2001), but the field is in its infancy. A major challenge is the creation of frameworks (e.g., Wainwright 2008) that allow these models to accommodate both social and physical processes with very different assumptions, levels of rules, and degrees of uncertainty.

As with the validation of global climate models (IPCC 2007), the most convincing validation of predictive models would be through simulation of past socioenvironmental interactions covering the last few decades and centuries: letting the model run from specified starting conditions in the past and making comparisons with long-term observations or reconstructions of reality. At present, attempts to do this are confined to bottom-up process-based models at local scales where human actions are essentially embodied as switches in land use (e.g., Anderson et al. 2006, Welsh et al. 2009). The development and testing of interactive models that can simulate the evolving nature of interactions among social and environmental states is a major research priority. Such models are predicated on the widespread existence of the four system characteristics identified above.

\section{CONCLUSION}

As climate change and sustainability science continue to galvanize the coupling of multiple research arenas, historical change in all its forms (Butzer 1996) must be included in studies of land systems. There is now overwhelming evidence that contemporary socioenvironmental systems are the product of self-organizing, evolutionary changes that cannot be fully understood without recourse to the past: either directly by extending the timescale of observation to capture the relevant timescale of interactions, or by interrogating past socioenvironmental changes to draw analogous lessons. Paleoenvironmental studies can provide long-term perspectives on past ecological conditions and processes, particularly the process responses to human-environment interactions (Dearing et al. 2006a). Environmental and human history can bring holistic and interdisciplinary perspectives to the interactions between humans and nature (e.g., Turner et al. 1995, Myllyntaus and Saikku 2001), drawing on a range of theoretical insights (Braudel 1949, Redman and Kinzig 2003). By integrating historical information of changes in human\&\#8211environment interactions, there is far greater opportunity of engaging with contemporary land systems and their future within a complex socioenvironmental framework (Wardell et al. 2003), a claim long noted (Butzer 2005) and 
long underemphasized. This integration will be facilitated by sustained, systematic efforts to address land (or coupled human-environment) systems, trends and trajectories, frequencies, thresholds and alternate steady states, slow and fast processes, legacies, and contingencies.

Responses to this article can be read online at: http://www.ecologyandsociety.org/voll5/iss4/art21/ responses/

\section{Acknowledgments:}

The paper was initiated at a pre-G8 Summit meeting of the Global Land Project "Dynamics and Pathways of Land Systems Change" held at the Hokkaido University, Japan, 25-26 June 2008. The meeting was supported by the special coordination funds of the Japan Science and Technology Agency.

\section{LITERATURE CITED}

Anderson, N. J., H. Bugmann, J. A. Dearing, and M.-J. Gaillard-Lemdahl. 2006. Linking palaeoenvironmental data and models to understand the past and to predict the future. Trends in Ecology and Evolution 21:696-704.

Auyang, S. Y. 1998. Foundations of complex systems theories: in economics, evolutionary biology, and statistical physics. Cambridge University Press, Cambridge, New York, USA.

Beddington, J. 2009. Presentation, UK Chief Scientist Advisor. GovNet SDUK09 Conference, Westminster, UK, March 2009. [online] URL: http ://www.govnet.co.uk/news/govnet/professor-sir-johnbeddingtons-speech-at-sduk-09.

Berkes, F., J. Colding, and C. Folke. editors. 2003. Navigating social-ecological systems: building resilience for complexity and change. Cambridge University Press, Cambridge, UK.

Biggs, R., S. R. Carpenter, and W.A. Brock. 2009. Turning back from the brink: detecting an impending regime shift in time to avert it. Proceedings of the National Academy of Sciences 106(3):826-831. DOI 10.1073 pnas.0811729106.
Bonabeau, E. 2002. Agent-based modelling: methods and techniques for simulating human systems. Proceedings of the National Academy of Sciences 99:7280-7287.

Bousquet, F., I. Bakam, H. Proton, and C. L. Page. 1998. Cormas: common-pool resources and multi-agent systems. Lecture Notes in Artificial Intelligence 1416:826-837.

Bradshaw, E. G., A. B. Nielsen, and N. J. Anderson. 2006. Using diatoms to assess the impacts of prehistoric, pre-industrial and contemporary land-use on Danish lakes. Regional Environmental Change 6:17-24.

Brand, S. 1999. The clock of the long now. Basic Books, New York, New York, USA.

Braudel, F. 1949. Écrits sur l'histoire. Éditions Flammarion, Paris, France.

Brooks, N., S. Di Lernia, N. Drake, I. Chiapello, M. Legrand, C. Moulin, and J. Prospero 2005. The environmental-society nexus in the Sahara from prehistoric times to the present day. The Journal of North African Studies 304:253-292.

Butzer, K. W. 1996. Ecology in the long view: settlement histories, agrosystemic strategies, and ecological performance. Journal of Field Archaeology 23:141-150.

Butzer, K. W. 2005. Environmental history in the Mediterranean world: cross-disciplinary investigation of cause-and-effect for degradation and soil erosion. Journal of Archaeological Science 32:1773-1800.

Carpenter, S. R. 2002. Ecological futures: building an ecology of the long now. Ecology 83: 20692083.

Carpenter, S. R., H. R. Mooney, J. Agard, D. Capistrano, R. S. DeFries, S. Díaz, T. Dietz, A. K. Duraiappah, A. Oteng-Yeboah, H. M. Pereira, C. Perrings, W. V. Reid, J. Sarukhan, R. J. Scholes, and A. Whyte. 2009. Science for managing ecosystem services: beyond the Millennium Ecosystem Assessment. Proceedings of the National Academy of Sciences 106:1305-1312

Chiverrell, R. C. 2006. Past and future perspectives upon landscape instability in Cumbria, northwest England. Regional Environmental Change 6:101114. 
Costanza, R., L. J. Graumlich, W. Steffen, C. L. Crumley, J.A. Dearing, K. Hibbard, R. Leemans, C. Redman, and D. Schimel, D. 2007. Sustainability or collapse: what can we learn from integrating the history of humans and the rest of nature. Ambio 36:522-527.

Coulthard, T. J. and M. G. Macklin. 2001. How sensitive are river systems to climate and land-use changes? A model-based evaluation. Journal of Quaternary Science 16:347-351.

Crutzen, P. J. 2002. Geology of mankind. Nature 415:23.

Cutter, S. 2001. American hazardscapes. Joseph Henry, Washington, D.C., USA.

Dean, J. S., G. J. Gummerman, J. M. Epstein, R. L. Axtell, A. C. Swedlund, M. T. Parker, and S. McCarroll. 2000. Understanding Anasazi culture change through agent-based modelling. Pages 179206 in Kohler, T. and G. J. Gumerman, editors. Dynamics in human and primate societies. Oxford University Press, Oxford, UK.

Dearing, J. A. 2007a. Human-environment interactions: learning from the past. In R. Costanza, L. Graumlich, and W. Steffen, editors. Integrated history and future of people on Earth. Dahlem Workshop Report 96. MIT Press, Cambridge, Massachusetts, USA.

Dearing, J.A. 2007b. Integration of world and earth systems: heritage and foresight. Pages 38-57 in A. Hornborg and C.L. Crumley, editors. The world system and the Earth system. Left Coast Press, Santa Barbara, California, USA.

Dearing, J. A. 2008. Landscape change and resilience theory: a palaeoenvironmental assessment from Yunnan, southwest China. The Holocene 18:117-127.

Dearing, J. A., R. W. Battarbee, R. Dikau, I. Larocque, and F. Oldfield. 2006a. Humanenvironment interactions: learning from the past. Regional Environmental Change 6:1-16.

Dearing, J. A., R. W. Battarbee, R. Dikau, I. Larocque, and F. Oldfield. 2006 b. Humanenvironment interactions: learning from the past. Regional Environmental Change 6:115-123.
Diamond, J. 2005. Collapse: how societies choose to fall or succeed. Viking, New York, New York, USA.

Diffenbaugh, N. S., F. Giorgi, L. Raymond, and B. Xunqiang. 2007. Indicators of 21 st century socio-climatic exposure. Proceedings of the National Academy of Sciences 104:95-198. DOI:10.1073/pnas.0706680105.

Dodson, J. R. and S. D. Mooney. 2002. An assessment of historic human impact on southeastern Australian environmental systems using late Holocene rates of environmental change. Australian Journal of Botany 50:455-464.

Doherty, S. J., S. Bojinski, A. Henderson-Sellers, K. Noone, D. Goodrich, N. I. Bindoff, J. A. Church, K. A. Hibbard, T. R. Karl, L. KajfezBogataj, A. H. Lynch, D. E. Parker, I. C. Prentice, V. Ramaswamy, R. W. Saunders, M. Stafford Smith, W. Steffen, T. F. Stocker, P. W. Thorne, K. E. Trenberth, M. M. Verstraete, and F. W.Zwiers. 2009. Lessons learned from IPCC AR4: future scientific developments needed to understand, predict, and respond to climate change. American Meteorological Society 90:497-513.

Eakin, H., and A. Luers. 2006. Assessing the vulnerability of social-environmental systems. Annual Review of Environment and Resources 31:365-394.

Elmqvist, T., C. Folke, M. Nyström, G. Peterson, J. Bengtsson, B. Walker, and J. Norberg. 2003. Response diversity, ecosystem change, and resilience. Frontiers in Ecology and the Environment 1:488-494.

European Spatial Planning Observation Network (ESPON). 2006. Territory matters for competitiveness and cohesion. ESPON synthesis report III. Denmark.

Foster, D. R. and J. Aber, editors. 2004. Forest in time. Ecosystem structure and function as a consequence of 1000 years of change. Synthesis volume of the Harvard Forest LTER Program. Yale University Press, New Haven, Connecticut, USA.

Foster, D. R., F. Swanson, J. Aber, I. Burke, N. Brokaw, D. Tilman, and A. Knapp. 2003. The importance of land-use legacies to ecology and conservation. Bioscience 53:77-88. 
Geist, H. J. and E. F. Lambin. 2002. Proximate causes and underlying driving forces of tropical deforestation. Bioscience 52:143-150.

Gell, P. A. 2007. River Murray wetlands: past and future, Pages 21-30 in Potter, E., A. Mackinnon, S. McKenzie, and J. McKay, J., editors. Fresh water: new perspectives on water in Australia. Melbourne University Press, Melbourne, Australia.

Gell, P. A., R. Jones, and A. MacGregor. 2007. Sensitivity of wetlands and water resources in southeeastern Australia to climate and catchment change. Past Global Changes News 15:13-15.

Gill, R. B. 2001. The Great Maya Droughts: water, life and death..University of New Mexico Press, Albuquerque, New Mexico, USA.

Glantz, M. H., editor. 1994. Drought follows the plow: cultivating marginal areas. Cambridge University Press, Cambridge, UK.

Global Land Project (GLP). 2005. Science plan and implementation strategy. IGBP report 53 / IHDP report 19. IGBP Secretariat, Stockholm, Sweden.

Grant, M.J. and M. E.Edwards. 2007 Conserving idealized landscapes: past history, public perception and future management in the New Forest (UK). Vegetation and Historical Archaeobotany 17:551562.

Grimm, N. B., S. H. Faeth, N. E. Golubiewski, C. L. Redman, J. Wu, X. Bai, and J. M. Biggs. 2008. Global change and the ecology of cities. Science 319:756-760.

Gunderson, L.H. and C.S. Holling, editors. 2002. Panarchy. Island Press, Washington, D.C., USA.

Haug, H. G., D. Günther, L. C. Peterson, D. M. Sigman, K. A. Hughen, and B. Aeschlimann. 2003. Climate and the collapse of Maya civilization. Science 299:1731-1735

Hnatkovska, V. V. and N. Loayza. 2004. Volatility and growth. Policy research working paper series 3184. The World Bank, Washington D.C., USA. [online] URL: http://www-wds.worldbank.org/external/ default/main?pagePK=64193027\&piPK=64187937 \& theSitePK=523679\&menuPK=64187510\&search
MenuPK $=64187283 \&$ theSitePK $=523679 \&$ entityID $=00001200920040203142259 \&$ searchMenuPK $=6$ 4187283\& theSitePK $=523679$.

Integrated History and Future of People on Earth (IHOPE). 2009. Science Prospectus [online] URL: http://www.aimes.ucar.edu/ihope/.

Intergovernmental Panel for Climate Change (IPCC). 2007. Fourth assessment report: synthesis report summary for policymakers and working group II report: impacts, adaptation and vulnerability summary for policymakers. IPCC Secretariat, Geneva, Switzerland. [online] URL: http://www.ipcc.ch/.

International Geosphere-Biosphere Programme (IGBP). 2008. Future climate change research and observations: GCOS, WCRP and IGBP learning from the IPCC fourth assessment report. IGBP Report 58. IGBP Secretariat, Stockholm, Sweden. [online] URL: http://www.igbp.net/documents/reso urces/Report 58.pdf.

Kasperson, J. X., R. E. Kasperson, and B. L. Turner, II, editors. 1995. Regions at risk: comparisons of threatened environments. United Nations University Press, Tokyo, Japan.

Kates, R. W., W. C. Clark, R. Corell, J. M. Hall, C. C. Jaeger, I. Lowe, J. J. McCarthy, H.-J. Schellenhuber, B. Bolin, N. M. Dickson, S. Faucheaux, G. C. Gallopin, A. Grübler, B. Huntley, J. Jäger, N. S. Jodha, R. E. Kasperson, A. Mabogunje, P. Matson, H. Mooney, B. Moore, III, T. O'Riordan, and U. Svedin. 2001. Sustainability science. Science 292:641-642.

Landes, D. S. 1998. The wealth and poverty of nations: why some are so rich and some so poor. W. W. Norton, New York, New York, USA.

Lansing, J. S. and J. N. Kremer. 1993. Emergent properties of Balinese water temple networks: coadaptation on rugged fitness landscape. American Anthropologist 95:97-114.

Lawrence, D., P. D'Odorico, L. Diekmann, M. DeLonge, R. Das, and J. Eaton. 2007. Ecological feedbacks following deforestation create the potential for a catastrophic ecosystem shift in tropical dry forest. Proceedings of the National Academy of Sciences 104:20696-20701. 
Leichenko, R. and K. O'Brien. 2008. Environmental change and globalization: double exposures. Oxford University Press, Oxford, U.K.

Lenton, T. M, H. Held, E. Kriegler, J. W. Hall, W. Lucht, S. Rahmstorf, and H.-J. Schellnhuber. 2008. Tipping elements in the Earth's climate system. Proceedings of the National Academy of Sciences 105: 1786-1793.

Liu, J., T. Dietz, S. R. Carpenter, M. Alberti, C. Folke, E. Moran, A. N. Pell, P. Deadman, T. Kratz, J. Lubchenco, E. Ostrom, Z. Ouyang, W. Provencher, C. L. Redman, S. H. Schneider, and W. W. Taylor. 2007. Complexity of coupled human and natural systems. Science 317:1513-1516.

Lüdeke, M. K. B., G. Petschel-Held, and Schellnhuber, H. -J. 2004. Syndromes of global change: the first panoramic view. Gaia 13:42-49.

Malhi, Y., J. Timmons Roberts, R. Betts, T. Killeen, W. Li, and C. Nobre. 2007. Climate change, deforestation and the fate of the Amazon. Science 319: 169-172.

Marsh, G. P. 1864. Man and nature, or, physical geography as modified by human action. Charles Scribner, New York, New York, USA.

Meybeck, M. 2003. Global analysis of river systems: from Earth system controls to Anthropocene syndromes. Philosophical Transactions of the Royal Society of London B. 358:1935-1955.

Meyer, W. B., K.W. Butzer, T. E. Downing, B. L. Turner, II, G. W. Wenzel, and L. Westcoat. 1998. Reasoning by analogy. Pages 217-289 in S. R. Raynor and E. L. Malone, editors. Human choices and climate change: the tools for policy analysis. Volume 3. Battelle, Columbus, Ohio, USA.

Millennium Ecosystem Assessment 2005. Ecosystems and human well-being: general synthesis. [online] URL http://www.maweb.org/en/ Synthesis.aspx.

Milly, P. C. D., J. Betancourt, M. Falkenmark, R. M. Hirsch, Z. W. Kundzewicz, D. P. Lettenmaier, and R. J. Stouffer. 2008. Stationarity is dead! Whither water management. Science 319:573574
Myllyntaus, T. and M. Saikku. 2001. Encountering the past in nature: essays in environmental history. Ohio University Press, Athens, Ohio, USA.

Nagendra, H. 2007. Drivers of reforestation in human-dominated forests. Proceedings of the National Academy of Sciences 104: 15218-15223.

Newell, B., C. L. Crumley, N. Hassan, E. F. Lambin, C. Pahl-Wostle, A. Underdalf, and R. Wasson. 2005. A conceptual template for integrative human-environment research. Global Environmental Change 15:299-307

Nicholson, E., G. M. Mace, P. R. Armsworth, G. Atkinson, S. Buckle, T. Clements, R. M. Ewers, J. E. Fa, T. A. Gardner, J. Gibbons, R. Grenyer, R. Metcalfe, S. Mourato, M. Muuls, D. Osborn, D. C. Reuma, C. Watson, and E. J. MilnerGulland. 2009. Priority research areas for ecosystem services in a changing world. Journal of Applied Ecology 466:1139-1144. DOI: 10.1111/ j.1365-2664.2009.01716.x

Nielsen, J. Ø and A. Reenberg, A. 2009a. Temporality and the problem with singling out climate as a current driver of change in a small West African village. Journal of Arid Environment 74 (4):464-474. DOI:10.1016/j.jaridenv.2009.09.019.

Nielsen, J.Ø and A. Reenberg. 2009b. Cultural barriers to climate change adaptation: a case study from Northern Burkina Faso. Global Environmental Change 20(1):142-152. DOI:10.1016/

gloenvcha.2009.10.002.

Oldfield, F. 1983. Man's impact on the environment: some recent perspectives. Geography 68:245-256.

Oldfield, F. 2005. Environmental change. Cambridge University Press, Cambridge, UK.

Olson, J. M., G. Alagarswamy, J. A. Andresen, D. J. Campbell, A. Y. Davis, J. Ge, M. Huebner, B. M. Lofgren, D. P. Lusch, N. J. Moore, B. C. Pijanowski, J. Qi, P. K.Thornton, N. M. Torbick, and J. Wang. 2008. Integrating diverse methods to understand climate-land interactions in East Africa. Geoforum 39:898-911. 
Ostrom, E. 2009. A general framework for analyzing sustainability of socio-ecological systems. Science 325:419-422.

Parker, D. C., S. M. Manson, M. A. Janssen, M. J. Hoffmann, and P. Deadman. 2003. Multi-agent systems for the simulation of land-use and landcover change: a review. Association of American Geographers 93:314-337.

Parton, W. J., M. P. Gutman, and D. Ojima. 2007. Long-term trends in population, farm income, and crop production in the Great Plains. BioScience 57:737-747

Past Global Changes (PAGES). 2009. Science plan and implementation strategy. IGBP report 57. IGBP Secretariat, Stockholm, Sweden. [online] URL: http://www.pages.unibe.ch/cgi-bin/WebObjects/ products.woa/wa/product?id=346.

Pielke, R. A. 2006. Land use and climate change. Science 310:1625-1626.

Pielke, R. A., Sr., R. L. Walko, L. T. Steyaert, P. L. Vidale, G. E. Liston, W. A. Lyons, and T. N. Chase. 1999. The influence of anthropogenic landscape changes on weather in South Florida. American Meteorological Society 127:1663-1673.

Redman, C. L. 2001. Human impacts on ancient environments. University of Arizona Press, Tuscon, Arizona, USA.

Redman, C. L. and A. P. Kinzig. 2003. Resilience of past landscapes: resilience theory, society, and the longue durée. Conservation Ecology 7(1): 14. [online] URL: www.ecologyandsociety.org/vol7/iss1/ art14/.

Reenberg, A. 2009. Embedded flexibility in coupled human-environmental systems in the Sahel: talking about resilience. Pages 132-158 in Hastrup, K. editor. The question of resilience: social implications of environmental changes. The Royal Danish Academy of Sciences and Letters, Copenhagen, Denmark.

Reenberg, A., T. L. Nielsen., and K. Rasmussen. 1998. Field expansions and reallocations in a desert margin region-land use pattern dynamics in a fluctuating biophysical and socio-economic environment. Global Environmental Change 8:309-327.
Rockström, J., W. Steffen, K. Noone, A. Persson, F. S. Chapin, III, E. F. Lambin, T. M. Lenton, M. Scheffer, C. Folke, H. J. Schellnhuber, B. Nykvist, C.A. de Wit, T. Hughes, S. van der Leeuw, H. Rodhe, S. Sörlin, P. K. Snyder, R. Costanza, U. Svedin, M. Falkenmark, L. Karlberg, R. W. Corell, V. J. Fabry, J. Hansen, B. Walker, D. Liverman, K. Richardson, P. Crutzen, and J. A. Foley. 2009. A safe operating space for humanity. Nature 461:472-475.

Rouchier, J., F. Bousquet, M. RequierDesjardins, and M. Antona. 2001. A multi-agent model for describing transhumance in North Cameroon: comparison of different rationality to develop a routine. Journal of Economic Dynamics and Control 25: 527-559.

Scheffer, M., S. R. Carpenter, J. A. Foley, C. Folke, and B. Walker. 2001. Catastrophic shifts in ecosystems. Nature 413:591-596.

Stafford Smith, D. M., N. Abel, B. Walker, and F. S. Chapin, III,. 2009. Drylands: coping with uncertainty, thresholds and changes in the state. Pages 171-195 in F. S. Chapin, III, G. P. Kofinas, and C. Folke, Carl, editors. Principles of ecosystem stewardship: resilience-based natural resource management in a changing world. Springer, New York, New York, USA.

Stafford Smith, D. M., G. M. McKeon, I. W. Watson, B. K. Henry, G. S. Stone, W. B. Hall, and S. M. Howden. 2007. Learning from episodes of degradation and recovery in variable Australian rangelands. Proceedings of the National Academy of Sciences 104:20690-20695

Steffen, W., A. Sanderson, P. Tyson, J. Jäger, P. Matson, B. Moore, III , F. Oldfield, K. Richardson, H.-J. Schellnhuber, B. L. Turner, II, and R. Wasson. 2004. Global change and the Earth system: a planet under pressure. Springer, Berlin, Germany.

Spangenberg, J.H., J. Martinez-Alier, I. Omann, I. Monterroso, and R. Binimelis. 2009. The DPSIR scheme for analysing biodiversity loss and developing preservation strategies. Ecological Economics 69:9-11.

Swetnam T. W., C. D. Allen, and J. L. Betancourt. 1999. Applied historical ecology: using the past to manage for the future. Ecological Applications 9:1189-1206. 
Tainter, J. A. 1988. The collapse of complex societies. Cambridge University Press, Cambridge, Massachusetts, USA.

Tallis, H. M. and P. Kareiva. 2006. Shaping global environmental decisions using socio-ecological models. Trends in Ecology and Evolution 21:562568.

Thomas, W. M., Jr. 1956. Man's role in changing the face of the earth. University of Chicago Press, Chicago, Illinois, USA.

Turner, B. L., II, W. C. Clark, R. W. Kates, J. F. Richards, J. T. Mathews, and W. B. Meyer. 1990. The earth as transformed by human action: global and regional changes in the biosphere over the past 300 years. Cambridge University Press, Cambridge, U.K.

Turner, B. L., II, J. G. Geoghegan, and D. R. Foster, editors. 2004. Integrated land-change science and tropical deforestation in the southern Yucatán: final frontiers. Oxford University Press, Oxford, UK.

Turner, B. L., II, A. Gomez Sal, F. González Bermúdez, and F.de Castri, editors. 1995. Global land-use change: a perspective from the Columbian encounter. Consejo Superior de Investigaciones Científicas, Madrid, Spain.

Turner, B. L., II, R. E. Kasperson, P. A. Matsone, J. J. McCarthy, R. W. Corell, L. Christensen, N. Eckley, J. X. Kasperson, A, Luerse, M. L. Martello, C. Polsky, A. Pulsipher, and A. Schiller. 2003. A framework for vulnerability analysis in sustainability science. Proceedings of the National Academy of Sciences 100:8074-8079.

Turner B. L., II, E. F. Lambin, and A. Reenberg. 2007. The emergence of land change science for global environmental change and sustainability. Proceedings of the National Academy of Sciences 104:20666-20671.

van der Leeuw, S. E. and C. Aschan-Leygonie. 2005. A long-term perspective on resilience in socio-natural systems. Pages 227-264 inU. Svedin and H. Lilienström, editors. Micro-meso-macro. Addressing complex systems couplings. World Scientific, London, UK.
Wainwright, J. 2008. Can modelling enable us to understand the role of humans in landscape evolution? Geoforum 39:659-674.

Walker, B., S. Carpenter, J. Anderies, N. Abel, G. Cumming, M. Janssen, L. Lebel, J. Norberg, G. D. Peterson, and R. Pritchard. 2002. Resilience management in social-ecological systems: a working hypothesis for a participatory approach. Conservation Ecology 6(1): 14. [online] URL: http ://www.consecol.org/vol6/iss1/art14.

Wardell, D.A.,A. Reenberg, and C. Tøtrup. 2003. Historical footprints in contemporary land use systems: forest cover changes in savannah woodlands in the Sudano-Sahelian zone. Global Environmental Change 13:235-254.

Welsh, K. E., J. A. Dearing, R. C. Chiverrell, and T. J. Coulthard. 2009. Testing a cellular modelling approach to simulating late Holocene sediment and water transfer from catchment to lake in the French Alps since 1826. The Holocene 19:785-798.

Wescoat, J. L. 1991. Resource-management-the long-term global trend. Progress in Human Geography 15:81-93.

Westley, F., S. R. Carpenter, W. A. Brock, C. S. Holling, and L. Gunderson. 2002. Why systems of people and nature are not just social and ecological systems. Pages 103-119 in L. H. Gunderson and C. S. Holling, editors. Panarchy: understanding transformation in human and natural systems. Island Press, Washington, D.C., USA.

Whitmore, T. M., B. L. Turner, II, D. L. Johnson, R. W. Kates, and T. R. Gottschang 1990. Longterm population change. Pages 25-39 in Turner, B. L., II, W. C. Clark, R. W. Kates, J. F. Richards, J. T. Mathews, and W. B. Meyer, editors. The earth as transformed by human action: global and regional changes in the biosphere over the past 300 years. Cambridge University Press, Cambridge, UK.

Willis, K. J. and S.A. Bhagwat. 2009. Biodiversity and climate change. Science 326:806-807.

Wolman, M. G. and J. P. Miller. 1960. Magnitude and frequency of forces in geomorphic processes. Journal of Geology 68:54-74. 
Zhang, D. D., P. Brecke, H. F. Lee, Y-Q. He, and J. Zhang. 2007. Global climate change, war, and population decline in recent human history. Proceedings of the National Academy of Sciences 104:19214-19219. 